\title{
Okul Öncesi Öğretmenlerinin Örgütsel Sosyalleşme İle Tükenmişlik Düzeyleri Arasındaki İlişkinin İncelenmesi ${ }^{1 *}$
}

\author{
Arife BAŞ SAKA \\ Öğretmen, MEB \\ Ridvan Hoca İmam Hatip Orta Okulu \\ arife.bas@gmail.com \\ Orcid ID: https://orcid.org/0000-0002-2355-0895

\section{Yemliha COŞKUN} \\ Doç. Dr, Kahramanmaraş Sütçü İmam Üniversitesi, \\ Eğitim Fakültesi, Eğitim Bilimleri Bölümü \\ ycoskun@ksu.edu.tr \\ Orcid ID: https://orcid.org/0000-0003-2231-3676
}

\section{Öz}

$\mathrm{Bu}$ araştırmanın amac1; okul öncesi öğretmenlerinin örgütsel sosyalleşme ile tükenmişlik düzeyleri arasındaki ilişkiyi incelemektir. Bu amaç doğrultusunda, okul öncesi öğretmenlerinin örgütsel sosyalleşme ile tükenmişlik düzeylerinin cinsiyete ve görev süresine göre farklılaşıp farklılaşmadığı incelenmiştir. Araştırmada, öğretmenlerin örgütsel sosyalleşme düzeylerini ölçmek için Kartal (2003) tarafından geliştirilen "Örgütsel Sosyalleşme Ölçeği”, tükenmişlik düzeylerini ölçmek için Ergin (1992) tarafindan Türkçe’ye uyarlanan "Maslach Tükenmişlik Envanteri” kullanılmıştır. Örneklem evrenden kademeli örnekleme yöntemiyle random (tesadüfî) olarak belirlenmiş ve araştırma 210'u kadın 20'si erkek olmak üzere toplam 230 öğretmen ile gerçekleştirilmiştir. Verilerin analizinde frekans, aritmetik ortalama ve standart sapma gibi betimsel istatistiklerin yanında Kruskal Wallis testi, Mann-Whitney U testi ve değişkenler arasındaki ilişkiyi belirlemek için Pearson Korelasyon Katsayısı kullanılmıştır. Araştırmanın sonucunda, okul öncesi öğretmenlerinin örgütsel sosyalleşme ile tükenmişlik düzeyleri arasında ters yönde anlamlı bir ilişki bulunmuştur. $\mathrm{Bu}$ sonuca göre örgütsel sosyalleşme düzeyi yükseldikçe, tükenmişlik düzeyi

${ }^{1}$ Makale Geliş/Kabul Tarihi: 30.03.2020 / 15.05.2020

* Bu makale Arife Baş’ın Yemliha Coşkun danışmanlığında yürüttüğü “'Okul Öncesi Öğretmenlerinin Örgütsel Sosyalleşme İle Tükenmişlik Düzeyleri Arasındaki İlişkinin İncelenmesi" başlıklı yüksek lisans tezinden üretilmiştir.

Künye Bilgisi: Baş Saka, A. ve Coşkun, Y. (2020). Okul Öncesi Öğretmenlerinin Örgütsel Sosyalleşme Ile Tükenmişlik Düzeyleri Arasındaki İlişkinin Incelenmesi. Kahramanmaraş Sütçü İmam Üniversitesi Sosyal Bilimler Dergisi, 17 (2), 729-749. DOI: $10.33437 /$ ksusbd.711270 
azalmaktadır. Bunların yanı sıra okul öncesi öğretmenlerinin örgütsel sosyalleşme ve tükenmişlik düzeylerinin her ikisinin de orta düzeyde olduğu görülmüştür.

Anahtar Kelimeler: Okul Öncesi Öğretmenleri, Örgütsel Sosyalleşme, Tükenmişlik.

\title{
The Examination Of The Relationship Between Organizational Socialization And Burnout Levels Of Preschool Teachers
}

\begin{abstract}
The main purpose of this research is to determine the relationship between organizational socialization and burnout levels of preschool teachers. For this purpose, it has been examined whether the levels of organizational socialization and burnout of preschool teachers differ according to gender and duration of duty. Within the study in order to determine the level of teachers' organizational socialization "Organizational Socialization Survey” developed by Kartal (2003) and "Maslach Burnout Inventory" adapted to Turkish by Ergin (1992) were used as data collection tools. The sample was randomly selected from the universe by graded sampling method and the study was conducted with 230 teachers, 210 of whom were female and 20 were male. In the analysis of the data frequency, among descriptive statistics such as mean, Kruskal Wallis, Mann Whitney U and standard deviation to determine the relationship between variables Pearson's correlation coefficient was used. As a result of the study, a significant negative correlation was found between organizational socialization and burnout levels of preschool teachers. According to this result, as organizational socialization level increases, burnout level decreases. In addition, the levels of organizational socialization and burnout of preschool teachers were both moderate.
\end{abstract}

Keywords: Preschool teachers, Organizational Socialization, Burnout.

\section{GİRIŞ}

Bir eğitim örgütü olan okullarda görev yapan öğretmenlerin başarılı bir şekilde sosyalleşme sürecinden geçmeleri onların örgüte bağlılıklarını ve uyumlarını büyük ölçüde artıırken, başarısız sosyalleşme yaşantıları tükenmişlik yaşamalarına ve örgütten ayrılmalarına zemin hazırlayacaktır (Kartal, 2007). Maslach ve Zimbardo'ya (1982) göre tükenmişliğin belki de en görünür etkisi, 
bireylerin iş performansındaki değişimdir. Tükenmişlik yaşayan bu bireyler daha kötü iş yaparlar, yaptıkları işi umursamazlar, daha üretken ve daha başarılı olmak gibi kaygıları yoktur, sonuçlarla ilgilenmezler (Dalkılıç, 2014).

Özellikle insanlar ile iletişimin yoğun olduğu meslek gruplarında tükenmişlik yoğun olarak görülmektedir. Başta hizmet kalitesi olmak üzere ciddi kayıplara yol açabilen bireyin iç kaynaklarının tükenmesi nedeni ile işini gereği gibi yerine getirememesi durumu tükenmişliğe bir örnektir (Balcıŏlu, Memetali ve Rozant, 2008). Tükenmişlik yaşayan kişi, bağlandığı bir yaşam tarzı ya da ilişkiden, beklentilerini elde edememesine bağlı bir yorgunluk ve hayal kırıklı̆̆ içindedir. Bunun sonucunda kişi içinde yoğun çatışmalar yaşar ve öz kaynakları, yaşam enerjisi ve işlev görme yeteneği tükenir (Tümkaya, 1996).

Yaşanan tükenmişliğin sonucunda ise ekonomik zararlar, elemanların işten ayrılması, hizmetin kalitesinin düşmesi gibi durumlar ortaya çıkmaktadır (Kaçmaz, 2005). Genel olarak tükenmişliğin sonuçları; işi savsaklama, çalışılan ortamdan uzaklaşma, çalma ve hırsızlık girişimleri, işten ayrılma, evlilik ve aile yaşantısında sorunlar, eş ve aile bireylerinden uzaklaşma şeklinde sıralanabilir (Dalkılıç, 2014; Solmuş, 2004). Bunun yanı sıra tükenmişlik sendromunu yaşayan kişiler sıkıntılarını azaltabilmek umuduyla içki, uyuşturucu, sakinleştirici tüketimini artırmakta ve zamanla bu maddelere bağımlı hale gelmektedirler (Izgar, 2000). Özetle, tükenmişlik tek başına onu yaşayana zarar getiren bir olgu değil, aynı zamanda bireyin etrafındaki her şeyi ve herkesi yıkıma uğratabilen bir olgudur (Dalkılıç, 2014).

Örgütün amaçlarını yerine getirebilmesi için tüm güçlerinin birbirleriyle eşgüdümlü olması zorunludur (Başaran, 2000). Kartal'a (2008) göre örgütte çalışan tüm bireylerin birbirleriyle eşgüdümlü olabilmesi için tüm üyelerin birbirini tanıması ve birbirleriyle uyumlu olması gerekir. Aynı örgütte çalışan bireylerin tanışmasını ve birbirleriyle uyumlu olmasını ise bireyin örgütte yaşadığı sosyalleşme süreci sağlar. Bu yüzden çalışan bireylerin örgüte uyum sağlamasında, örgütteki değer, norm ve tutumlara uygun hareket edebilmesinde sosyalleşme sürecinin önemi yadsınamaz. Bu açıdan bakıldığında gerek iş görenin yaptı̆̆ı işten doyum sağlaması, gerekse de örgütün amaçlarının gerçekleşmesi, sosyalleşme sürecinin etkililiğine bağlıdır.

Örgütsel sosyalleşme süreci, örgüte girişten itibaren başlayan bir süreçtir (Zonana, 2011). Örgütsel sosyalleşme süreci giriş, sosyalleşme ve ayrılma olmak üzere üç aşamadan oluşmaktadır. Birinci aşama olan giriş aşamasında bireyler, örgütte var olan değer, tutum ve beklentilerle karşılaşırlar (Kartal, 2007). İkinci aşama olan sosyalleşme aşaması, bireyin yeni durumun parçası olmasını dışarıdan biri olmaktan çıkarak, içeriden birisi olmasını sağlayan bir değişim 
sürecidir (Balc1, 2000). Son aşama ise başarısız sosyalleşme süreci geçiren bireylerin örgüte uyum sağlayamayarak işten ayrılmalarıdır (Louis, 1980).

Örgütsel sosyalleşme sürecinin başarılı veya başarısız olduğunu gösteren bazı belirtiler vardır ve bunlara örgütsel sosyalleşme belirtileri denir. Örgütsel sosyalleşme belirtileri ise iş doyumu, motivasyon, örgütsel bağlllık ve örgütsel kabullenme olarak belirtilmektedir (Kartal, 2007). Bu belirtiler aşağıda sıra ile açıklanmıştır.

İş Doyumu: İş doyumu, işin özellikleriyle iş görenlerin istekleri birbirine uyduğu zaman gerçekleşen ve iş görenin işinden hoşnutluk duymasını belirleyen bir olgudur (Akıncı, 2002). İş doyumunun, çalışanın, işyeri ile ilgili bilgi ve deneyimlerinin artmasıyla birlikte oluştuğu, belirli koşullar altında artma ya da azalma eğilimi gösteren dinamik bir yapıyı içerdiği ve gelişiminden çok daha hızlı bir şekilde düşme eğilimi göstereceği söylenebilir (Solmuş, 2004). Bu noktada, çalışanda iş doyumu ya da doyumsuzluğu oluşturan faktörler şu şekilde sıralanabilir: Bireyin kişilik özellikleri, yaş, cinsiyet, işin kendisi, ücret ve personel, örgütteki çalışma süresi (deneyim), bireyin özel yaşamı, gelişme ve yükselme olanakları, övülmek, fiziksel ortam, iş arkadaşları, denetim ve yönetim biçimi (Solmuş, 2004; Zöğ, 2007).

Motivasyon: Güdüleme (motivasyon), iş görenleri çalışmaya isteklendirme ve örgütte verimli çalıştıkları takdirde kişisel ihtiyaçlarını en iyi şekilde tatmin edeceklerine inandırma sürecidir (Yüksel, 2007). Kartal'a (2007) göre bir örgüt iş görenlerinin performansını artırmak istiyorsa onların ihtiyaçlarını gidererek motivasyonlarını sağlamalıdır. Motivasyon sürecinin başarılı olabilmesi için bireyin ihtiyaçları ile örgütün amaçlarının uygun olması gerekmektedir.

Örgütsel Bağlılık: Örgütsel bağlılık, örgüt ile çalışanların amaçlarının bir bütünlük ve uyum içinde olmasıdır (Güney, 2011). Örgüte bağlanmış bir birey, bağlandığı örgütün amaç ve değerlerine güçlü biçimde inanmakta, bu örgütün istek ve beklentilerine gönüllü biçimde uymakta, örgüt ile birlikteliğini sürdürmeyi güçlü biçimde amaçlamaktadır (Celep, 2014). Örgütsel bağl1lığın en göze çarpan sonuçları ise, iş başarımı, örgütle kalma, devamsızlık, işi yavaşlatma ve iş gücü devri olarak nitelendirilmektedir (Güney, 2011).

Örgütsel Kabullenme: Kartal'a (2007) göre örgütsel sosyalleşmeyi, örgütün değerlerini, tutumlarını ve normlarını kabullenme ve bunlara uyum sağlama olarak belirtmek mümkündür. Örgütsel sosyalleşme aynı zamanda kuralları öğrenme, telkin edilme ve eğitilme, bir örgütte nelerin önemli olduğunu öğretme sürecidir. Bu süreç temelde değişim ve öğrenimi içerir ancak her çeşit öğrenimi kapsamaz. Yalnızca örgüt açısından her üyenin öğrenmesi ve kabullenmesi gereken değer, norm ve davranış biçimlerini kapsar. Bu kabullenme üyeliğin bedeli olarak tanımlanabilir. 
Eğitim kurumlarında çalışan öğretmenler açısından örgütsel sosyalleşme, okulun temel değer, norm, felsefe ve misyonunun öğrenilmesidir (Çelik, 1998). Öğretmenlerin okuluna uyum sağlayabilmesi ve bağlanabilmesi için örgütsel sosyalleşme sürecinden başarılı bir şekilde geçmesi gerekmektedir. Özkan'a (2015) göre öğretmenlerin okullarına, öğrencilerine, öğretim aktivitelerine, mesleğe ve meslektaşlarına bağlılı̆̆ 1 araçsal bağl1lığın ötesinde, öğretmenlik mesleğine içsel bağlılık duymalarına ve başarılı olmalarına güçlü bir etki yapmaktadır.

Elci'ye (2008) göre eğitim kurumları, belli toplumsal amaçları gerçekleştirmek için etkili ve verimli çalışmalar yapmak zorundadır. Okullardaki iş görenlerin yüksek düzeyde performans göstermelerini engelleyen en önemli sorunlardan biri de motivasyon, iş doyumu, örgütsel bağlllık ve örgütsel kabullenme eksikliğidir. Öğretmenlerde mesleklerine yönelik motivasyon, iş doyumu, örgütsel bağlllık ve kabullenme eksiklikleri, işe gitmede isteksizlik, çevresine kırıcı davranma, hata yapma, isabetsiz kararlar verme, işbirliği kuramama gibi davranışlara neden olmaktadır. $\mathrm{Bu}$ da öğretmenin çevresi ile sağlıklı iletişim kurabilen sosyal bir kişi olmasını olumsuz yönde etkilemektedir. $\mathrm{Bu}$ anlamda, çevresiyle sağlıklı ilişkiler kuran öğretmenler görevlerini iyi bir şekilde yerine getirecektir.

Eğitimin ilk basamağı olan okul öncesi eğitim, eğitim-öğretim hayatında en önemli dönemdir. Akkurt'a (2008) göre okul öncesi eğitiminde çocuğun yetenek ve becerilerini geliştirmek ve ona rehberlik etmek için alanında kendini uzman olarak yetiştirmiş, okul öncesi öğretmenlerine ihtiyaç vardır. Okul öncesi eğitimde görevli bir öğretmen, çok çeşitli bilgi ve becerileri öğrencilere kazandırabilecek düzeyde olmalıdır. Öğretmenin özellikleri, mesleğini severek yapmas1, öğrencilere karşı ilgi ve tutumu, okul öncesi eğitiminin geliştirilmesi bakımından büyük önem taşımaktadır. Zira okul öncesi dönemdeki çocuğun yaşamındaki en önemli faktör çevresindeki kişilerdir. Bu sebeple okul öncesi öğretmeni, anne ve babadan sonra çocuk için en önemli kişidir. Çocuğun bu yıllarda kazanacağı olumlu özellikler onun daha sonraki yaşantılarını olumlu yönde etkileyecektir. Tüm bu sebeplerden dolayı okul öncesi eğitim vermekle görevli olan okul öncesi öğretmenlerinin, çocuklara faydalı bir eğitim verebilmesi için okulunu sevmesi, okulda başarılı bir sosyalleşme süreci geçirmesi ve tükenmişlik hissine kapılmaması gerekmektedir.

Okul öncesi eğitimde çocuklar ilk defa bir öğretmenle karşılaştıklarından ilk tanıdıkları öğretmen onlar için çok önemli olmaktadır. Çocukların karşılaşıtıkları ilk öğretmen, hayatlarının geri kalan kısmını ve eğitime bakış açılarını etkileyecektir. Okul öncesi öğretmenlerinin mesleğine bağl1lı̆̆ , iş doyumu, motivasyonu, mesleğini kabullenme ve tükenmişlik düzeyleri çocuklara karşı davranışlarını etkileyeceğinden öğretmenlerin çalıştıkları kurum içerisinde 
sosyalleşmeleri çok önemlidir. Çalıştığ 1 kurum içerisinde sosyalleşemeyen öğretmen kendini yalnız hissedebilir, çalıştığı kurumdan, çocuklardan ve mesleğinden soğuyabilir. $\mathrm{Bu}$ olumsuz durum da beraberinde tükenmişlik sendromunu getirebilir ve tükenmişlik sendromu yaşayan okul öncesi öğretmenleri görevini iyi bir şekilde yerine getiremeyecektir.

Okul öncesi öğretmenlerinin örgütsel sosyalleşme ile tükenmişlik düzeylerini belirlemek ve aralarındaki ilişkiyi ortaya çıkarabilmek için böyle bir araştırmanın yapılmasına ihtiyaç duyulmuştur. $\mathrm{Bu}$ araştırma, okul öncesi eğitim öğretmenlerinin örgütsel sosyalleşme ve tükenmişlik düzeylerinin belirlenmesine ve örgütsel sosyalleşme ile tükenmişlik düzeyleri arasındaki ilişkinin ortaya çıkarılmasına katkı sağlayacaktır. Ayrıca bu araştırmanın, alan yazına kaynak oluşturması açısından diğer çalışmalara yol göstereceği, elde edilecek sonuçların örgütsel sosyalleşme ile ilgili benzer çalışmalara temel oluşturacağ 1 düşünülmektedir.

\section{Araştırmanın Amacı}

$\mathrm{Bu}$ araştırmanın amacı; okul öncesi öğretmenlerinin örgütsel sosyalleşme ile tükenmişlik düzeyleri arasındaki ilişkinin incelenmesidir. $\mathrm{Bu}$ amaç doğrultusunda aşağıdaki sorulara cevap aranmaktadır.

1. Okul öncesi öğretmenlerinin örgütsel sosyalleşme düzeyleri nedir?

2. Okul öncesi öğretmenlerinin tükenmişlik düzeyleri nedir?

3. Okul öncesi öğretmenlerinin örgütsel sosyalleşme ve alt boyutları ile tükenmişlik düzeyleri arasında anlamlı bir ilişki var mıdır?

4. Okul öncesi öğretmenlerinin örgütsel sosyalleşme düzeyleri cinsiyete ve görev süresine göre anlamlı biçimde farklılaşmakta mıdır?

5. Okul öncesi öğretmenlerinin tükenmişlik düzeyleri cinsiyete ve görev süresine göre anlamlı biçimde farklılaşmakta mıdır?

\section{YÖNTEM}

\section{Araştırmanın Modeli}

$\mathrm{Bu}$ araştırma, ilişkisel tarama modelinde betimsel bir çalışmadır. Tarama modeli; bir evren içinde seçilen bir örneklem üzerinde yapılan çalışmalar yoluyla evren genelindeki eğilim, tutum veya görüşlerin nicel olarak betimlenmesini sağlar (Creswell, 2013). İlişkisel tarama modelleri ise, iki ve daha çok sayıdaki değişken arasında birlikte değişim varlığını ve/veya derecesini belirlemeyi amaçlayan araştırma modelleridir (Karasar, 2014). 


\section{A. Bas Saka-Y. Coskun Okul Öncesi Öğretmenlerinin Örgütsel...}

\section{Örneklem}

Araştırmanın evrenini, 2014-2015 eğitim-öğretim yılında Kahramanmaraş’a bağlı Onikişubat ve Dulkadiroğlu ilçe merkezlerinde, resmi anaokulu, ilkokul ve orta okullarda (toplam 108 okul) görev yapmakta olan 400 okul öncesi öğretmeni oluşturmaktadır. Örneklem, kademeli örnekleme yöntemiyle random (tesadüfî) olarak belirlenmiştir. Kademeli örnekleme, kümelerin çok sayıda alınması, örneklemi aşırı ölçüde büyütüyorsa, seçilen her küme içinden de küme ya da eleman örneklemesine gidilebilen bir tekniktir (Karasar, 2014).

Araştırma resmi anaokulunda (14 anaokulu) çalışan okul öncesi öğretmenlerinden 118, ilkokulda (27 ilkokul) çalışan okul öncesi öğretmenlerinden 77 , ortaokulda (15 ortaokul) çalışan okul öncesi öğretmenlerinden ise 35 olmak üzere toplamda 56 okulda görev yapmakta olan 230 okul öncesi öğretmeni ile gerçekleştirilmiştir. Örnekleme alınan kişilerin demografik özellikleri ise şöyledir: 230 öğretmenin 210'u kadın 20'si erkektir. Araştırmaya katılan öğretmenlerin 24 yaş ve altı 32 kişi, 25-34 yaş arası 138 kişi, 35-44 yaş arası 52 kişi, 45 ve üstü yaş arasında ise sekiz kişi olduğu görülmüştür. Araştırmaya katılan öğretmenlerden 0-5 yıl görev süresi olan 72 kişi, 6-11 yıl görev süresi olan 111 kişi, 12-17 yıl görev süresi olan 28 kişi, 18 ve üstü görev süresi olan öğretmenler ise sekiz kişidir.

\section{Veri Toplama Araçları}

Bu araştırmada veri toplama aracı olarak Örgütsel Sosyalleşme Ölçeği (ÖSÖ) ve Maslach Tükenmişlik Envanteri kullanılmıştır. Öğretmenlerin örgütsel sosyalleşme düzeylerini ölçmek amacıyla Kartal (2003) tarafından geliştirilen ÖSÖ, bağımsız dört alt ölçekten oluşmaktadır. Bu boyutlar: iş doyumu, motivasyon, bağlilık ve kabullenmedir. Ölçekte toplam 60 soru bulunmaktadır. $\mathrm{Bu}$ sorulardan 13 tanesi iş doyumu, 16 tanesi motivasyon, 18 tanesi bağlılık ve 13 tanesi de kabullenme boyutlarıyla ilgilidir. Katılımcıların belirtilen ifadelere ilişkin katılım düzeylerini belirlemede Likert Tipi Beşli Derecelendirme Ölçeği kullanılmıştır. Ölçek; (1) Hiç, (2) Çok az, (3) Ara sıra, (4) Büyük ölçüde, (5) Tam seçeneklerinden oluşmuştur. ÖSÖ'nün $5,21,22,25,35,36,42,43,49,52,56$ ve 59. maddelerinin tersine çevrilmiş (reverse) madde olduğu belirlenmiştir. $\mathrm{Bu}$ maddelerin seçenekleri veri analizi sırasında; (1) Tam, (2) Büyük ölçüde, (3) Ara sıra, (4) Çok Az, (5) Hiç olarak düzenlenmiştir. Ölçeğin güvenirliği ile ilgili yapılan araştırmalar sonucunda ölçeğin genelinin güvenirlik katsayısının 0.76 olduğu görülmüştür.

Araştırmada bireylerin tükenmişlik düzeylerini belirlemek amacı ile kullanılan Maslach Tükenmişlik Envanteri Maslach ve Jackson (1981) tarafından geliştirilmiştir. Ülkemizde ilk Türkçeye uyarlanması Ergin (1992) tarafindan yapılmış ve 235 kişiye (doktor, hemşire, öğretmen, avukat ve polis meslek 
gruplarından) uygulanmıştır. Bu uygulamalar sonucunda; orijinalinde 7 dereceli likert tipi olan ölçek 5 dereceli likert tipi olan son halini almıştır. Ölçeğin orijinal formu 7'li likert tipinden oluşmaktadır. Ölçekte toplam 22 madde bulunmaktadır. Akkurt'a (2008) göre Maslach tükenmişlik envanterinde duygusal tükenme, duyarsızlaşma ve kişisel başarısızlık olmak üzere üç alt boyut bulunmaktadır. Duygusal tükenme 1, 2, 3, 6, 8, 13, 14, 16, 20 maddelerini; duyarsızlaşma 5, 10, 11, 15, 22 maddelerini ve kişisel başarısızlık ise 4, 7, 9, 12, 17, 18, 19, 21 maddelerini oluşturmaktadır. Ölçeğin güvenirlik çalışması araştırmaya katılan 150 öğretmenden elde edilen veri kullanılarak ölçeğin geneli ve her bir alt ölçek için Cronbach's Alfa güvenirlik katsayılarının hesaplanması ile yapılmışırı. Buna göre; güvenirlik katsayıları testin geneli için 0,88; DT alt boyutu için 0,84; D alt boyutu için 0,57 ve KB alt boyutu için 0,77 olarak hesaplanmıştır. Ölçekten alınabilecek en yüksek ve en düşük puanlar duygusal tükenme alt boyutunda en az dokuz, an fazla 45; duyarsızlaşma alt boyutunda en az beş, en fazla 25; kişisel başarısızlık alt boyutunda ise en az sekiz, an fazla 40 olabilir.

\section{Verilerin Toplanması ve Analizi}

Araştırma sürecinde elde edilen veriler, SPSS 16.0 istatistik paket programı aracılığıyla çözümlenmiştir. Verilerin analizinde frekans, aritmetik ortalama ve standart sapma gibi betimsel istatistiklerin yanında, Kruskal Wallis, Mann Whitney U ve örgütsel sosyalleşme ile tükenmişlik düzeyleri arasındaki ilişkiyi ve ÖSÖ alt boyutları olan iş doyumu-motivasyon-bağl1lık-kabullenme ile tükenmişlik düzeyleri arasındaki ilişkileri belirlemek üzere "Pearson Korelasyon Katsayısı" kullanılmıştır.

\section{BULGULAR}

\section{Okul Öncesi Öğretmenlerinin Örgütsel Sosyalleşme Düzeylerine İlişkin Bulgular}

Araştırmaya katılan okul öncesi öğretmenlerinin örgütsel sosyalleşme düzeylerini belirlemek için kullanılan ölçeğin alt boyutlarına ait aritmetik ortalamalar ve standart sapmalar belirlenmiş ve Tablo 1'de verilmiştir.

Tablo 1. Okul Öncesi Öğretmenlerinin Örgütsel Sosyalleşme Düzeyleri Puanlarının Aritmetik Ortalama ve Standart Sapmaları

\begin{tabular}{lccc}
\hline Alt Boyutlar & $\mathbf{N}$ & $\mathbf{X}$ & S.S \\
\hline İş Doyumu & 230 & 43.84 & 8.05 \\
Motivasyon & 230 & 56.91 & 8.02 \\
Bağl1lık & 230 & 64.18 & 7.12 \\
Kabullenme & 230 & 43.96 & 6.37 \\
Toplam & 230 & 208.91 & 24.89 \\
\hline
\end{tabular}


Tablo 1'de görüldüğü gibi okul öncesi öğretmenlerinin iş doyumu düzeylerinin aritmetik ortalamasının 43.84, standart sapmasının 8.05; motivasyon düzeylerinin aritmetik ortalamasının 56.91, standart sapmasının 8.02; bağl1lık düzeyinin aritmetik ortalamasının 64.18 , standart sapmasının 7.12; ve kabullenme düzeyinin aritmetik ortalamasının 43.96, standart sapmasının 6.37 olduğu görülmektedir.

Bu bulguya göre, okul öncesi öğretmenlerinin iş doyumu ve kabullenme düzeylerinin orta düzeyde; motivasyon ve bağl1lık düzeylerinin yüksek düzeyde olduğunu söylemek mümkündür. Okul öncesi öğretmenlerinin mesleklerini kabullendikleri ancak yaptıkları işten yeterince doyum sağlayamadıkları söylenebilir. Aynı zamanda okul öncesi öğretmenlerinin kurumlarına yeterince bağlı oldukları ve yaptıkları işte gereken motivasyonu sağladıkları düşünülmektedir. Okul öncesi öğretmenlerinin örgütsel sosyalleşme düzeylerinin genel olarak orta düzeyde olduğu görülmüştür.

2. Okul Öncesi Öğretmenlerinin Tükenmişlik Düzeylerine İlişkin Bulgular

Araştırmaya katılan okul öncesi öğretmenlerinin tükenmişlik düzeylerini belirlemek için kullanılan ölçeğin alt boyutlarına ait aritmetik ortalamalar ve standart sapmalar belirlenmiş ve Tablo 2'de verilmiştir.

Tablo 2. Okul Öncesi Öğretmenlerinin Tükenmişlik Düzeyleri Puanlarının Aritmetik Ortalama ve Standart Sapmaları

\begin{tabular}{lccc}
\hline Alt Boyutlar & $\mathbf{N}$ & $\overline{\mathbf{X}}$ & $\mathbf{S . S}$ \\
\hline Duygusal Tükenme & 230 & 21.86 & 6.93 \\
Duyarsızlaşma & 230 & 7.96 & 3.00 \\
Kişisel Başarı & 230 & 32.62 & 4.35 \\
Toplam & 230 & 62.46 & 8.25 \\
\hline
\end{tabular}

Tablo 2'de görüldüğü gibi okul öncesi öğretmenlerinin duygusal tükenme düzeylerinin aritmetik ortalamasının 21.86, standart sapmasının 6.93; duyarsızlaşma düzeyinin aritmetik ortalamasının 7.96, standart sapmasının 3.00; kişisel başarısı düzeyinin aritmetik ortalamasının 32.62, standart sapmasının 4.35 olduğu görülmektedir.

$\mathrm{Bu}$ bulguya göre, okul öncesi öğretmenlerinin genel olarak tükenmişlik düzeylerinin orta düzeyde olduğunu belirtmek mümkündür.

3. Okul Öncesi Öğretmenlerinin Örgütsel Sosyalleşme Düzeyleri İle Tükenmişlik Düzeyleri Arasındaki İlişkiye Yönelik Bulgular 
Okul öncesi öğretmenlerinin örgütsel sosyalleşme düzeyleri ile tükenmişlik düzeyleri arasındaki ilişkiyi belirlemek amacıyla "Pearson Momentler Çarpımı Korelâsyon Katsayısı”" tekniğinden yararlanılmış ve sonuçlar Tablo 3'de verilmiştir.

Tablo 3. Öğretmenlerin Örgütsel Sosyalleşme Düzeyleri ve Alt Boyutları İle Tükenmişlik Düzeylerinin Pearson Momentler Çarpımı Korelâsyon Katsayısı

Sonuçlar1

\begin{tabular}{lc}
\hline \multicolumn{2}{c}{ Değişkenler } \\
\hline İş Doyumu & Tükenmişlik Düzeyi \\
Motivasyon & $-.358^{*}$ \\
Bağl1lik & $-.267^{*}$ \\
Kabullenme & -.034 \\
Örgütsel Sosyalleşme & $-.158^{*}$ \\
\hline $\mathrm{N}=230$ & $-.253^{*}$ \\
\hline
\end{tabular}

Tablo 3'te görüldüğg̈ gibi, okul öncesi öğretmenlerinin iş doyumu düzeyleri ile tükenmişlik düzeyleri arasında orta düzeyde ve ters yönde anlamlı bir ilişki bulunmaktadır $(\mathrm{p}<.01)$. Bu bulguya göre, iş doyumu düzeyleri yüksek olan okul öncesi öğretmenlerinin, tükenmişlik düzeylerinin düşük olduğunu belirtmek mümkündür. Motivasyon ve tükenmişlik düzeyleri arasında yapılan pearson momentler çarpımı korelâsyon katsayısı sonuçlarına bakıldığında, okul öncesi öğretmenlerinin motivasyon düzeyleri ile tükenmişlik düzeyleri arasında düşük düzeyde ve ters yönde anlamlı bir ilişki olduğu görülmektedir $(\mathrm{p}<.01) . \mathrm{Bu}$ bulguya göre, motivasyon düzeyleri yüksek olan okul öncesi öğretmenlerinin, tükenmişlik düzeylerinin düşük olduğunu belirtmek mümkündür. Bağl1lık ve tükenmişlik düzeyleri arasında yapılan pearson momentler çarpımı korelâsyon katsayısı sonuçlarına göre ise, okul öncesi öğretmenlerinin bağl1lık düzeyleri ile tükenmişlik düzeyleri arasında anlamlı bir ilişki olmadığı görülmektedir. Kabullenme ve tükenmişlik düzeyleri arasında yapılan pearson momentler çarpımı korelâsyon katsayısı sonuçları incelendiğinde, okul öncesi öğretmenlerinin kabullenme düzeyleri ile tükenmişlik düzeyleri arasında düşük düzeyde ve ters yönde anlamlı bir ilişki olduğu görülmektedir $(\mathrm{p}<.01) . \mathrm{Bu}$ bulguya göre, kabullenme düzeyleri yüksek olan okul öncesi öğretmenlerinin, tükenmişlik düzeylerinin düşük olduğunu belirtmek mümkündür. Örgütsel sosyalleşme ve tükenmişlik düzeyleri arasında yapılan pearson momentler çarpımı korelâsyon katsayısı sonuçlarına bakıldığında, öğretmenlerin örgütsel sosyalleşme ile tükenmişlik düzeyleri arasında düşük düzeyde ve ters yönde anlamlı bir ilişki olduğu görülmektedir $(\mathrm{p}<.01)$. Bu bulguya göre, örgütsel sosyalleşme düzeyleri yüksek olan okul öncesi öğretmenlerinin, tükenmişlik düzeylerinin düşük olduğunu belirtmek mümkündür. 


\section{Okul Öncesi Öğretmenlerinin Örgütsel Sosyalleşme Düzeylerinin Cinsiyet ve Görev Süresi Değişkenlerine İliş̧kin Bulgular}

Okul öncesi öğretmenlerinin örgütsel sosyalleşme düzeylerinin cinsiyet değişkenine göre Mann-Whitney U testi sonuçları Tablo 4.1'de sunulmuştur.

Tablo 4.1. Okul Öncesi Öğretmenlerinin Örgütsel Sosyalleşme Düzeylerinin Cinsiyet Değişkenine Göre Mann-Whitney U Testi Sonuçları

\begin{tabular}{cccccc}
\hline Cinsiyet & $\mathbf{N}$ & $\begin{array}{c}\text { Sıra } \\
\text { Ortalaması }\end{array}$ & $\begin{array}{c}\text { Sıra } \\
\text { Toplamı }\end{array}$ & $\mathbf{U}$ & $\mathbf{p}$ \\
\hline Erkek & 20 & 81.85 & 1637.00 & 1427.00 & .018 \\
Kadın & 210 & 118.70 & 24928.00 & & \\
\hline
\end{tabular}

Tablo 4.1'de görüldüğü gibi, cinsiyet değişkenine göre öğretmenlerin örgütsel sosyalleşme düzeyleri arasında anlamlı bir farklılık bulunmuştur $(\mathrm{p}<.05)$. Bu bulguya göre, kadın öğretmenlerin örgütsel sosyalleşme düzeylerinin erkek öğretmenlerin örgütsel sosyalleşme düzeylerinden anlamlı biçimde daha yüksek olduğunu belirtmek mümkündür.

Okul öncesi öğretmenlerinin örgütsel sosyalleşme düzeylerinin görev süresi değişkenine göre Kruskall Wallis testi sonuçları Tablo 4.2'de sunulmuştur.

Tablo 4.2. Okul Öncesi Öğretmenlerinin Örgütsel Sosyalleşme Düzeylerinin Görev Süresi Değişkenine Göre Kruskall Wallis Testi Sonuçları

\begin{tabular}{lcccccc}
\hline Görev Süresi & N & $\begin{array}{c}\text { Sira } \\
\text { Ortalaması }\end{array}$ & sd & $\boldsymbol{x 2}$ & $\mathbf{p}$ & Fark \\
\hline $0-5$ y1l (1) & 72 & 106.13 & 3 & 13.56 & .004 & $1<4$ \\
6-11 y1l (2) & 111 & 109.72 & & & & $2<4$ \\
12-17 y1l (3) & 28 & 129.71 & & & & \\
18 yıl ve üstü (4) & 19 & 163.82 & & & & \\
\hline
\end{tabular}

Tablo 4.2'de görüldüğ̈̈ gibi, görev süresi değişkenine göre öğretmenlerin örgütsel sosyalleşme düzeyleri arasında anlamlı bir farklılık bulunmuştur $(\mathrm{p}<.05)$. İstatistiksel olarak anlamlı farklılıkların hangi gruplar arasında olduğunu belirlemek amacıyla ikili Mann-Whitney $U$ testi karşılaştırmaları yapılmıştır.

Öğretmenlerin örgütsel sosyalleşme düzeylerinde; 18 y1l ve üstünde çalışmış olan öğretmenler ile $05-y_{11}$ ve 6-11 yıl aralığında çalışmış olan öğretmenler arasında anlamlı farklılık gözlenmiş, diğer gruplar arasında anlamlı bir farklılık gözlenmemiştir. Örgütsel sosyalleşme alt boyutunda aralarında anlamlı farklılık gözlenen grupların sıra ortalamasına bakıldığında, 18 yıl ve üstünde çalışmış olan 
öğretmenlerin örgütsel sosyalleşme düzeylerinin, 0-5 yıl ve 6-11 yıl aralığında çalışmış olan öğretmenlerin örgütsel sosyalleşme düzeylerinden anlamlı biçimde daha yüksek olduğu görülmektedir. $\mathrm{Bu}$ bulguya göre, okul öncesi öğretmenlerinin görev süresi arttıkça örgütsel sosyalleşme düzeylerinin de arttı̆̆ını söylemek mümkündür.

\section{Okul Öncesi Öğretmenlerinin Tükenmişlik Düzeylerinin Cinsiyet ve Görev Süresi Değişkenlerine İlişkin Bulgular}

Okul öncesi öğretmenlerinin tükenmişlik düzeylerinin cinsiyet değişkenine göre Mann Whitney U testi sonuçları Tablo 5.1'de sunulmuştur.

Tablo 5.1. Okul Öncesi Öğretmenlerinin Tükenmişlik Düzeylerinin Cinsiyet Değişkenine Göre Mann-Whitney U Testi Sonuçları

\begin{tabular}{cccccc}
\hline Cinsiyet & $\mathbf{N}$ & $\begin{array}{c}\text { Sira } \\
\text { Ortalamas }\end{array}$ & $\begin{array}{c}\text { Sira } \\
\text { Toplamı }\end{array}$ & U & p \\
\hline Erkek & 20 & 136.35 & 2727.00 & 1683.00 & .142 \\
Kadın & 210 & 113.51 & 23838.00 & & \\
\hline
\end{tabular}

Tablo 5.1'de görüldüğü gibi, cinsiyet değişkenine göre öğretmenlerin tükenmişlik düzeyleri arasında anlamlı bir farklılık bulunmamıştır ( $>$ >.05). Bu bulguya göre, okul öncesi öğretmenlerinin cinsiyet değişkenine bağlı olarak tükenmişlik düzeyleri arasında bir farklılığın olmadığını söylemek mümkündür.

Okul öncesi öğretmenlerinin tükenmişlik düzeylerinin görev süresi değişkenine göre Kruskall Wallis testi sonuçları Tablo 5.2'de sunulmuştur.

Tablo 5.2. Okul Öncesi Öğretmenlerinin Tükenmişlik Düzeylerinin Görev

\begin{tabular}{lccccc}
\multicolumn{4}{c}{ Süresi Değişkenine Göre Kruskall Wallis Testi Sonuçları } \\
\hline Görev Süresi & N & $\begin{array}{c}\text { Sira } \\
\text { Ortalaması }\end{array}$ & sd & $\boldsymbol{x 2}$ & $\mathbf{p}$ \\
\hline $0-5$ y1l & 72 & 110.78 & 3 & 3.24 & .356 \\
6-1 y y1 & 111 & 114.42 & & & \\
12-17 yıl & 28 & 136.09 & & & \\
18 y1l ve üstü & 19 & 109.32 & & & \\
\hline
\end{tabular}

Tablo 5.2'de görüldüğü gibi, görev süresi değişkenine göre öğretmenlerin tükenmişlik düzeyleri arasında anlamlı bir farklılık bulunmamıştır ( $\mathrm{p}>.05)$. Bu bulguya göre, okul öncesi öğretmenlerinin görev süresi değişkenine bağlı olarak tükenmişlik düzeyleri arasında bir farklılığın olmadığı görülmüştür. 


\section{A. Bas Saka-Y. Coskun Okul Öncesi Öğretmenlerinin Örgütsel...}

\section{SONUÇ, TARTIŞMA ve ÖNERILLER}

Yapılan istatistiksel işlemler sonucunda elde edilen bulgulara göre, okul öncesi öğretmenlerinin örgütsel sosyalleşme düzeylerinin orta düzeyde olduğu görülmektedir. Örgütsel sosyalleşme alt boyutlarında ise; okul öncesi öğretmenlerinin iş doyumu ve kabullenme düzeylerinin orta düzeyde; motivasyon ve bağl1lik düzeylerinin yüksek düzeyde olduğu sonucuna ulaşılmıştır. Başka bir deyişle okul öncesi öğretmenlerinin çalıştıkları kurumlarda orta düzeyde sosyalleşme yaşadıkları görülmektedir. Okul öncesi öğretmenlerinin sosyalleşme düzeylerinin yüksek olmaması, okul öncesi öğretmenlerine çalıştıkları kurumlarda teneffüs hakkı tanınmamasından kaynaklanmakta olduğu söylenebilir. Millî Eğitim Bakanlığı okul öncesi eğitim ve ilköğretim kurumları yönetmeliğinde "Okul öncesi eğitim kurumlarında günde ellişer dakikalık aralıksız 6 etkinlik saati süre ile eğitim yapılır" ibaresi bulunmaktadır (MEB, 2014). Yönetmelikte bulunan bu maddeyle okul öncesi öğretmenlerinin teneffüse çıkma imkânının olmadığı ve meslektaşlarıyla kurumlarında bir araya gelemediği anlaşılmaktadır. Bu sebepten dolayı, okul öncesi öğretmenleri kurumlarında sınıflarından çıkabilecek zamanı bulamamakta, aynı zamanda günlük ihtiyaçlarını karşılamakta da sıkıntı çekmektedir. Okul öncesi öğretmenleri çalıştıkları okullarda teneffüse çıkamadıklarından diğer öğretmenlerle iletişime geçememekte, dolayısıyla sosyalleşme düzeyleri yeterli düzeyde olmamaktadır.

Elde edilen bulgulara göre, okul öncesi öğretmenlerinin tükenmişlik ölçeği alt boyutları olan duygusal tükenme, duyarsızlaşma ve kişisel başarı düzeylerinin normal düzeyde olduğu görülmektedir. Tükenmişlik ölçeği toplam puanlarına bakıldığında, okul öncesi öğretmenlerinin genel olarak tükenmişlik düzeylerinin orta düzeyde olduğu görülmektedir. Teltik'in (2009) yaptığı araştırmada, okul öncesi öğretmenlerinin tükenmişlik düzeylerinin, tükenmişlik alt boyutları bakımından duygusal tükenme ve duyarsızlaşma orta, kişisel başarı boyutunda yüksek düzeyde olduğu görülmüştür. Toplu'nun (2012) yaptığ1 araştırmada ise, okul öncesi ve ilköğretim öğretmenlerinin duygusal tükenme, duyarsızlaşma ve kişisel başarı boyutlarında "düşük" düzeyde tükenmişlik yaşadıkları bulunmuştur. Umay (2015) yürüttüğg̈ çalışmasında, psikolojik danışman ve rehberlik öğretmenlerinin tükenmişlik düzeylerine bakıldığında tükenmişlik alt boyutu olan duyarsızlaşma ve duygusal tükenme düzeylerinin orta düzeyde olduğu, kişisel başarı duygusunda azalma tükenmişlik oranının ise düşük düzeyde olduğu görülmüştür. Öğretmenlerin toplam tükenmişlik düzeylerinin ise orta düzeyde olduğu sonucuna ulaşılmıştır. Çolakoğlu'nun (2014) müzik öğretmenleri üzerine yaptığ tükenme düzeylerinin en fazla olduğu, bunu duyarsızlaşma ve kişisel başarısızlık puanlarının izlediği, kişisel başarısızlık ve duyarsızlaşma açısından tükenmişlik düzeylerinin çok ciddi seviyelerde olmadığ 1 görülmüsstür. Koralay’ın (2014) 
yürüttüğü çalışmada ise, resmi ilkokullarda görev yapan öğretmenlerin tükenmişlik düzeyleri; ölçeğin duygusal tükenme ve kişisel başarı alt boyutları ile ölçek genelinde "az"; buna karşın duyarsızlaşma boyutunda "çok az" düzeyde olduğu bulunmuştur.

Araştırmadan elde edilen bulgulara göre, okul öncesi öğretmenlerinin örgütsel sosyalleşme düzeyleri ile tükenmişlik düzeyleri arasında düşük düzeyde ve ters yönde anlamlı bir ilişki bulunmuştur. $\mathrm{Bu}$ bulguya göre, okul öncesi öğretmenlerinin örgütsel sosyalleşme düzeyleri yükseldikçe tükenmişlik düzeyleri azalmaktadır. Bu durumun, okulunda başarılı bir sosyalleşme süreci yaşayan okul öncesi öğretmenlerinin işine isteyerek ve mutlu bir şekilde gitmesinden kaynaklandığını söylemek mümkündür. Güneş'in (2014) İngilizce öğretmenleri üzerine yaptığı araştırma bulguları bu bulguyu destekler niteliktedir. Güneş'in yaptığı araştırma sonucuna göre, öğretmenlerin tükenmişlik ile örgütsel sosyalleşme düzeyleri arasında ters orantılı bir ilişki gözlenmiştir. Bu sonuca göre örgütsel sosyalleşme düzeyi yükseldikçe, tükenmişlik düzeyi azalmaktadır. Çetin ve Kurban'ın (2016) kıdemi 0-2 yıl olan memurlar ile yaptığı araştırma bulguları da bu bulguları destekler niteliktedir.

Örgütsel sosyalleşme ölçeği alt boyutları ile tükenmişlik düzeyi arasında yapılan istatistiksel işlemler sonucunda elde edilen bulgulara göre, bağlllık alt boyutu ile tükenmişlik düzeyi arasında anlamlı bir ilişki bulunmadığı görülmüştür. Motivasyon ve kabullenme alt boyutları ile tükenmişlik düzeyi arasında düşük düzeyde ve ters yönde anlamlı bir ilişki bulunduğu sonucuna ulaşılmıştır. $\mathrm{Bu}$ bulgunun sonucunda motivasyon ve kabullenme düzeyleri yüksek olan öğretmenlerin, tükenmişlik düzeylerinin düşük olduğu ortaya çıkmıştır. İş doyumu ile tükenmişlik düzeyi arasında ise orta düzeyde ve ters yönde anlamlı bir ilişki bulunduğu görülmüsstür. Gürbüz (2008) ve Teltik’in (2009) okul öncesi öğretmenleri üzerine yaptıkları araştırmaların bulguları bu bulguyu destekler niteliktedir. Bu araştırmaların sonucunda iş doyumu düzeyleri yüksek olan okul öncesi öğretmenlerinin tükenmişlik düzeylerinin düşük olduğu görülmüştür. Bu durumun, mesleğini yaparken yeterli iş doyumu sağlayan okul öncesi öğretmenlerinin mutlu olmalarından ve dolayısıyla tükenmişlik düzeylerinin düşük olmasından kaynaklandığını söylemek mümkündür. Sonuç olarak mesleğini severek yapan, yaptı̆̆ işten doyum sağlayan, işinde motivasyonunu koruyan ve işini kabullenen okul öncesi öğretmenlerinin tükenmişlik düzeylerinin düşük olacağını belirtmek mümkündür.

Okul öncesi öğretmenlerinin örgütsel sosyalleşme düzeylerinin cinsiyet değişkenine göre farklılaşıp farklılaşmadığını incelemek amacıyla yapılan istatistiksel işlemler sonucunda elde edilen bulgulara göre, kadın öğretmenlerin örgütsel sosyalleşme düzeyinin erkek öğretmenlerden daha yüksek olduğu görülmüştür. Anaokulu, ilkokul ve ortaokullarda çalışan okul öncesi öğretmenleri 


\section{A. Bas Saka-Y. Coskun Okul Öncesi Öğretmenlerinin Örgütsel...}

arasında kadınlar yoğunluktadır ve erkek öğretmenlerin sosyalleşme düzeylerinin kadın öğretmenlerin sosyalleşme düzeylerinden düşük olmasının, erkek öğretmenlerin bu meslekte daha az yer almasından kaynaklandığını söylemek mümkündür. Demirer (2014) ortaöğretimde görev yapan öğretmenler üzerine yaptığı araştırmada bu bulguya benzer sonuçlara ulaşmıştır. Bu sonuca göre sosyalleşmenin tüm alt boyutlarında ve sosyalleşme ölçeği toplam puanında kadın öğretmenlerin sosyalleşme düzeylerinin erkek öğretmenlere göre daha fazla olduğu görülmüştür. Bu bulgunun aksine Elci (2008) ilköğretim okullarında görevli sınıf ve branş öğretmenleri üzerine yaptığı araştırmasında erkek öğretmenlerin, kadın öğretmenlere göre iş doyumu ve kabullenme boyutlarında örgütsel sosyalleşme düzeylerinin anlamlı biçimde daha yüksek olduğu sonucunu bulmuştur. Vural'ın (2015) ilkokul ve ortaokul yönetici ve öğretmenleri üzerine yaptığı araştırmasında, Çalışkan'ın (2009) özel eğitim öğretmenleri ile yaptı̆̆ araştırmasında, Mutlu'nun (2008) ortaöğretim kurumlarında görev yapan öğretmenlerle yaptığı araştırmasında, Çapar'ın (2007) ilköğretim okullarında görevli sınıf ve branş öğretmenleri üzerine yaptığı araştırmasında ve Kartal'ın (2005) ilköğretim okullarında görev yapan yönetici ve öğretmenler üzerine yaptığ1 araştırmasında ise öğretmenlerin örgütsel sosyalleşme düzeylerinin cinsiyet değişkenine göre anlamlı bir farklılık göstermediği görülmüştür.

Örgütsel sosyalleşme ölçeğinden alınan toplam puana bakıldığında, okul öncesi öğretmenlerinin görev süreleri arttıkça örgütsel sosyalleşme düzeylerinin de arttı̆̆ı görülmektedir. Bu durumun okul öncesi öğretmenlerinin görev süreleri arttıkça daha fazla kurum değiştirmelerinden ve daha fazla insanla karşılaşmalarından kaynaklandığını söylemek mümkündür. Çalışkan'ın (2009) özel eğitim öğretmenleri üzerine yaptığı araştırmasında benzer bulgulara ulaşılmıştır. Bu bulguya göre, mesleki deneyimler geliştikçe ve yeni yaşantılar kazanıldıkça öğretmenlerin örgütsel sosyalleşme özellikleri de olumlu yönde değişmektedir. Demirer'in (2014) ortaöğretimde görev yapan öğretmenler üzerine yaptığı araştırmasında, Karadağ'ın (2012) beden eğitimi ve spor öğretmenleri üzerine yaptığı araştırmasında, Erdoğan (2012) ve Ö̈zkan'ın (2005) ilköğretim okullarında görev yapan öğretmenler üzerine yaptıkları araştırmalarında görev süresi arttıkça öğretmenlerin örgütsel sosyalleşme düzeylerinin arttığı sonucuna ulaşılmıştır.

Okul öncesi öğretmenlerinin tükenmişlik ölçeği toplam puanlarına bakıldığında, cinsiyet değişkenine göre anlamlı bir farklılı̆̆ın olmadığ görülmüştür. Koralay'ın (2014) resmi ilkokullarda görev yapan öğretmenler üzerine, Çolakoğlu'nun (2014) müzik öğretmenleri üzerine, Toplu (2012) ve Ertürk'ün (2012) ise okul öncesi öğretmenleri üzerine yaptıkları araştırma bulguları bu bulguyu destekler niteliktedir. Bu bulgulara göre tükenmişlik düzeyinin cinsiyet değişkenine göre farklılaşmadığı görülmüştür. 
Okul öncesi öğretmenlerinin tükenmişlik ölçeği toplam puanlarına bakıldığında, görev süresi değişkenine göre anlamlı bir farklılık bulunmamıştır. $\mathrm{Bu}$ bulguya göre, okul öncesi öğretmenlerinin görev süresi değişkenine bağlı olarak tükenmişlik düzeyleri arasında bir farklılığın olmadığını söylemek mümkündür. Bu bulguyu destekler nitelikte olan Umay'ın (2015) psikolojik danışman ve rehberlik öğretmenleri üzerine yaptığı araştırmasında, görev süresi değişkenine göre öğretmenlerin tükenmişlik düzeylerinin farklılaşmadığ 1 sonucuna ulaşılmıştır.

\section{Öneriler}

Araştırmada elde edilen bulgular ve sonuçlar işı̆̆ında şu önerilerde bulunulabilir:

Uygulamaya Yönelik Öneriler:

1. Okul öncesi öğretmenlerinin örgütsel sosyalleşme düzeylerinin orta düzeyde olduğu sonucuna ulaşılmıştır. Öğretmenlerin örgütsel sosyalleşmelerinin başarıyı artırdığı göz önünde bulundurulursa, öğretmenlerin daha fazla sosyalleşmeleri gerektiğini söylemek mümkündür. Okul öncesi öğretmenlerinin kurumlarında yeterli düzeyde sosyalleşebilmeleri için, onlara Milli Eğitim Bakanlığı tarafından teneffüs hakkı verilmesi ve diğer öğretmenlerle iletişim kurmalarının sağlanması gerekmektedir. Zira, çalıştıkları kurumlarda diğer öğretmenlerle bir araya gelemeyen okul öncesi öğretmenleri sınıflarından çıkamamakta ve kurumlarından habersiz bir şekilde eğitim vermeye devam etmektedir. Bu da okul öncesi öğretmenlerinin motivasyonunu düşürerek, onları mesleklerinden soğutmaktadır. Okul öncesi öğretmenlerinin iş doyumunun, motivasyonunun, bağlllığının ve kabullenme düzeylerinin yeterli düzeyde olması için, okul öncesi öğretmenlerine teneffüs hakkı tanınmalı ve kurumlarında diğer meslektaşlarıyla bir araya gelmelerine firsat verilmelidir.

2. Okul öncesi öğretmenlerinin tükenmişlik düzeylerinin orta düzeyde olduğu sonucuna ulaşılmıştır. Eğitimin daha kaliteli ve verimli gerçekleşmesi için tükenmişlik düzeyi yüksek olan öğretmenler Milli Eğitim Bakanlığı tarafından tespit edilmeli, gerekli eğitim ve psikolojik destek sağlanmalıdır.

3. Örgütsel sosyalleşme düzeyi yüksek olan okul öncesi öğretmenlerinin tükenmişlik düzeylerinin düşük olduğu sonucuna ulaşılmıştır. Tükenmişlik düzeyi düşük olan öğretmenler, mesleklerine daha bağlı olmakta, kendilerini geliştirmekte ve görevini başarılı bir şekilde yerine getirmektedirler. Bu yüzden okul öncesi öğretmenlerinin örgütlerinde sosyalleşme yaşantılarının başarılı olabilmesi için gerek yöneticiler gerekse bakanlık tarafından öğretmenlere firsat verilmelidir. 
Araştırmalara Yönelik Öneriler:

1. Bu araştırma, okul öncesi öğretmenleriyle Kahramanmaraş iline bağlı Onikişubat ve Dulkadiroğlu ilçe merkezlerinde gerçekleştirilmiştir. Benzer araştırmalar, farklı kademelerde görev yapan öğretmenlerle ve farklı illerde veya ilçelerde görev yapan öğretmenlerle de yapılmalıdır.

2. Bu araştırmada veri toplama aracı olarak anket kullanılmıştır. Bu konu ile ilgili benzer araştırmalarda gözlem ve görüşme gibi farklı nitel araştırma yöntemleri kullanılabilir.

\section{KAYNAKÇA}

Akıncı, Zeki (2002). "Turizm Sektöründe İş Gören İş Tatminini Etkileyen Faktörler (Beş Yıldızlı Konaklama İşletmelerinde Bir Uygulama)”, Akdeniz Üniversitesi İ.İ.B.F. Dergisi, No: 4, November, ss. 1-25.

Akkurt, Zeynep (2008). Okul Öncesi Öğretmenlerinin İş Doyumu ve Tükenmişlik Düzeylerinin İncelenmesi (İstanbul-Pendik Örneği) (Yüksek Lisans Tezi), Selçuk Üniversitesi Sosyal Bilimler Enstitüsü, Konya.

Balcı, Ali (2000). Örgütsel Gelişme, Geliştirme, Pegem Yayıncılık, Ankara.

Balcıoğlu, İbrahim- Memetali, Seyfi- Rozant, Rakel (2008). "Tükenmişlik Sendromu”, Dirim Tip Gazetesi, Sayı: 83, ss. 99-104.

Başaran, İbrahim E. (2000). Örgütsel Davranış İnsanın Üretim Gücü, Nobel Yayın Dağıtım, Ankara.

Celep, Cevat (2014). Eğitim Örgütlerinde Örgütsel Adanma. Nobel Yayın Dağıtım, Ankara.

Creswell, John W. (2013). Araştırma Deseni: Nitel, Nicel ve Karma Yöntem Yaklaşımları (Çev. Ed. Demir, S. B.), Eğiten Kitap, Ankara.

Çalışkan, İsenbike G. (2009). Öğretmenlerin Örgütsel Sosyalleşmelerinin Okul Yöneticilerinin Liderlik Tarzlarına İlişkin Algılarına Göre İncelenmesi Özel Eğitim Öğretmenleri Örneği (Yüksek Lisans Tezi), Maltepe Üniversitesi Sosyal Bilimler Enstitüsü, İstanbul.

Çapar, Dilek (2007). İlköğretim Okulu Sınıf ve Branş Öğretmenlerinin Örgütsel Sosyalleşme Düzeyleri (Antalya İli Örneği) (Yüksek Lisans Tezi), Akdeniz Üniversitesi Sosyal Bilimler Enstitüsü, Antalya. 
Çelik, Vehbi (1998). “Alan Dışından Gelen Sınıf Öğretmenlerinin Sosyalizasyonu”, Ege Üniversitesi Eğitim Fakültesi Dergisi, Cilt. 4, Sayı: 14, ss. 191-208.

Çetin, Cemile \& Kurban, Pınar (2016). Tükenmişlik ve Örgütsel Sosyalleşme İlişkisi-Kıdemi 0-2 Yıl Olan Memur Çalışanlar Örneklemi-, 20. Ulusal Ergonomi Kongresi, 26-28 Eylül 2014, Ankara.

Çolakoğlu, İbrahim (2014). Ortaokullarda Görev Yapan Müzik Öğretmenlerinin Mesleki Tükenmişlik Düzeylerinin İncelenmesi (Yüksek Lisans Tezi), İstanbul Aydın Üniversitesi-Yıldız Teknik Üniversitesi Sosyal Bilimler Enstitüleri, İstanbul.

Dalkılıç, Olga S. (2014). Çalışma Hayatında Tükenmişlik Sendromu (Tükenmişlikle Mücadele Teknikleri), Nobel Yayın Dağıtım, Ankara.

Demirer, Sibel (2014). Öğretmenlerin Örgütsel Sosyalleşme ve Özdeşleşme Düzeyleri İle Birlikte Çalışma Yeterlikleri Arasındaki İlişki (Yüksek Lisans Tezi), Abant İzzet Baysal Üniversitesi Eğitim Bilimleri Enstitüsü, Bolu.

Elci, Devrim (2008). İlköğretim Okulu Öğretmenlerinin Örgütsel Sosyalleşme Düzeylerinin İncelenmesi (Yüksek Lisans Tezi), Selçuk Üniversitesi Sosyal Bilimler Enstitüsü, Konya.

Erdoğan, Ufuk (2012). İlköğretim Okullarının Bürokratik Yapıları İle Öğretmenlerin Örgütsel Sosyalleşme Düzeyleri Arasındaki İlişki (Malatya İli Örneği) (Yüksek Lisans Tezi), İnönü Üniversitesi Eğitim Bilimleri Enstitüsü, Malatya.

Ergin, Canan (1992). Doktor ve Hemşirelerde Tükenmişlik ve Maslach Tükenmişlik Ölçeğinin Uyarlanması. VII. Ulusal Psikoloji Kongresi Bilimsel Çalışmaları, 22-25 Eylül 1992, Hacettepe Üniversitesi, Ankara.

Ertürk, Müge (2012). Özel ve Devlet Okullarında Çalışan Okul Öncesi Öğretmenlerin Demografik Değişkenlere Bağlı Olarak Mesleki Tükenmişlik ve Anksiyete Düzeylerinin Karşılaştırılması (Yüksek Lisans Tezi), Maltepe Üniversitesi Sosyal Bilimler Enstitüsü, İstanbul.

Güney, Salih (2011). “Örgütsel Davranış”, Nobel Yayın Dağıtım, Ankara.

Güneş, Çiğdem (2014). Teacher Burnout and Organizational Socialization: The Case Of Efl Teachers In Turkey (Yüksek Lisans Tezi), Gazi Üniversitesi Eğitim Bilimleri Enstitüsü, Ankara. 
Gürbüz, Zehra (2008). Kars İlinde Görevli Okul Öncesi Öğretmenlerinin İş Tatmin Düzeyleri ve Mesleki Tükenmişlik Düzeylerinin İncelenmesi (Yüksek Lisans Tezi), Marmara Üniversitesi Eğitim Bilimleri Enstitüsü, İstanbul.

Izgar, Hüseyin (2000). Okul Yöneticilerinin Tükenmişlik Düzeyleri (Burnout), Nedenleri ve Bazı Etken Faktörlere Göre İncelenmesi (Orta Anadolu Örneği) (Doktora Tezi), Selçuk Üniversitesi Sosyal Bilimler Enstitüsü, Konya.

Kaçmaz, Nazmiye (2005). “Tükenmişlik (Burnout) Sendromu”, İstanbul Tip Fakültesi Dergisi, Say1: 68, ss. 29-32.

Karadağ, Tuba F. (2011). Beden Eğitimi ve Spor Öğretmenlerinin Örgütsel Sosyalleşme Düzeyleri (Elazığ İli Örneği) (Yüksek Lisans Tezi), Fırat Üniversitesi Sağlık Bilimleri Enstitüsü, Elazığ.

Karasar, Niyazi (2014). Bilimsel Araştırma Yöntemi, Nobel Akademi Yayınc1l1k, Ankara.

Kartal, Sadık (2003). İlköğretim Okulu Yönetici ve Öğretmenlerinin Örgütsel Sosyalleşme Düzeyleri (Ankara İli Örneği) (Doktora Tezi), Ankara Üniversitesi Eğitim Bilimleri Enstitüsü, Ankara.

Kartal, Sadık (2005). “illköğretim Okulu Yönetici ve Öğretmenlerinin Örgütsel Sosyalleşmeleri (Ankara İli Örneği)”, Ege Eğitim Dergisi, Cilt. 2, Say1: 6, ss. 99-112.

Kartal, Sadık (2007). Eğitimde Örgütsel Sosyalleşme, Maya Akademi Yayın Dağıtım, Ankara.

Kartal, Sadık (2008). "Eğitim Çalışanlarının Örgütsel Sosyalleşmelerinde İlköğretim Okulu Yöneticilerinin Katkıları ve İki Örnek Olay", İnönü Üniversitesi Eğitim Fakültesi Dergisi, Cilt. 15, Sayı: 9, Bahar, ss. 75-88.

Koralay, Fatma D. (2014). İlkokulda Görev Yapan Öğretmenlerin Mesleki Tükenmişlik Düzeyi (Yüksek Lisans Tezi), Dokuz Eylül Üniversitesi Eğitim Bilimleri Enstitüsü, İzmir.

Louis, Meryl R. (1980). “Surprise and Sense Making: What Newcomers Experience in Entering Unfamiliar Organizational Settings", Administrative Science Quarterly, Vol. 2, No: 25, Jun, ss. 226-251. 
Maslach, Christina \& Jackson, Susan E. (1981). "The Measurement of Experienced Burnout. Journal of Occupational Behaviour”, No: 2, ss. 99-113.

Maslach, Christina \& Zimbardo, Philip G. (1982). Burnout-The Cost of Caring, Englewood Cliffs, New Jersey.

MEB (2014). "Millî Eğitim Bakanlığı Okul Öncesi Eğitim ve İlköğretim Kurumları Yönetmeliği”, Resmi Gazete, No: 29072, ss. 1-24.

Mutlu, Bakile (2008). İstanbul Ortaöğretim Okullarında Okul Kültürü ve Öğretmenlerin Örgütsel Sosyalleşmeleri (Yüksek Lisans Tezi), Beykent Üniversitesi Sosyal Bilimler Enstitüsü, İstanbul.

Özkan, Yasemin (2005). Örgütsel Sosyalleşme Sürecinin Öğretmenlerin Örgüte Bağlılıklarına Etkisi (Ordu İli Örneği) (Yüksek Lisans Tezi), Gazi Üniversitesi Eğitim Bilimleri Enstitüsü, Ankara.

Solmuş, Tarık (2004). İş Yaşamında Duygular ve Kişilerarası İlişkiler (Psikoloji Penceresinden İnsan Yönetimi), Beta Basım Yayım Dağıtım, İstanbul.

Teltik, Hilal (2009). Okul Öncesi Öğretmenlerinin Mesleki Yeterlilik Algılarının İş Doyumu ve Tükenmişlik Düzeyleriyle İlişkisinin Belirlenmesi (Yüksek Lisans Tezi), Marmara Üniversitesi Eğitim Bilimleri Enstitüsü, İstanbul.

Toplu, Nermin Y. (2012). Okul Öncesi ve İlköğretim Öğretmenlerinin Tükenmişlik Düzeyleri (Yüksek Lisans Tezi), Adnan Menderes Üniversitesi Sosyal Bilimler Enstitüsü, Aydın.

Tümkaya, Songül (1996). Öğretmenlerdeki Tükenmişlik Görülen Psikolojik Belirtiler ve Başaçıkma Davranışları (Doktora Tezi), Çukurova Üniversitesi Sosyal Bilimler Enstitüsü, Adana.

Umay, Gamze (2015). Psikolojik Danışman ve Rehberlik Öğretmenlerinin İş Doyumu Ve Tükenmişlik Düzeylerinin İlişkisi (Yüksek Lisans Tezi), Yeditepe Üniversitesi Eğitim Bilimleri Enstitüsü, İstanbul.

Vural, Fadile (2015). İlkokul ve Ortaokul Yönetici ve Öğretmenlerinin Örgütsel Sosyalleşme Düzeylerinin İncelenmesi (İzmir İli Örneği) (Yüksek Lisans Tezi), Okan Üniversitesi Sosyal Bilimler Enstitüsü, İstanbul.

Yüksel, Öznur (2007). “İnsan Kaynakları Yönetimi”, Gazi Kitabevi, Ankara. 
Zonana, Murat (2011). İş Stresinin İş Görenlerin Örgütsel Sosyalleşme Düzeylerine Etkileri ve Bir Araştırma (Yüksek Lisans Tezi), Marmara Üniversitesi Sosyal Bilimler Enstitüsü, İstanbul.

Zöğ, Hasan (2007). İstanbul İli Kağıthane İlçesinde Görev Yapan İlköğretim Okulu Öğretmenlerinin Örgütsel Adanmışlıkları İle İş Doyumları Arasındaki İlişki (Yüksek Lisans Tezi), Yıldız Teknik Üniversitesi Sosyal Bilimleri Enstitüsü, İstanbul. 